\title{
The Critical Role of IL-10 in the Antineuroinflammatory and Antioxidative Effects of Rheum tanguticum on Activated Microglia
}

\author{
Jie Meng $\mathbb{D}^{1},{ }^{1}$ Junjun Ni $\mathbb{D}^{1}{ }^{1}$ Zhou Wu $\mathbb{D},{ }^{1,2}$ Muzhou Jiang, ${ }^{1}$ Aiqin Zhu $\mathbb{D}^{3}{ }^{3}$ Hong Qing, \\ and Hiroshi Nakanishi $\mathbb{D}^{1}$ \\ ${ }^{1}$ Department of Aging Science and Pharmacology, Faculty of Dental Sciences, Kyushu University, Fukuoka 812-8582, Japan \\ ${ }^{2}$ OBT Research Center, Faculty of Dental Sciences, Kyushu University, Fukuoka 812-8582, Japan \\ ${ }^{3}$ Institution of Geriatric, Qinghai Provincial Hospital, Xining 810007, China \\ ${ }^{4}$ School of Life Science, Beijing Institute of Technology, Haidian District, Beijing 100081, China
}

Correspondence should be addressed to Hiroshi Nakanishi; nakan@dent.kyushu-u.ac.jp

Received 12 December 2017; Revised 28 February 2018; Accepted 18 March 2018; Published 26 April 2018

Academic Editor: Mithun Sinha

Copyright ( 2018 Jie Meng et al. This is an open access article distributed under the Creative Commons Attribution License, which permits unrestricted use, distribution, and reproduction in any medium, provided the original work is properly cited.

\begin{abstract}
Rheum tanguticum Maxim. ex Balf. (Rt), a traditional Tibetan medicine, is known to exert various bioactivities, including antiinflammatory and antioxidative activities. The present study was conducted to investigate anti-inflammatory and antioxidative effects of Rt on activated microglia. Rt $(10 \mu \mathrm{g} / \mathrm{ml})$ significantly inhibited the mean protein level of interleukin- $1 \beta$ (IL- $1 \beta)$ in the organotypic hippocampal slice cultures following treatment with chromogranin A (CGA, $10 \mathrm{nM})$ and pancreastatin (10 nM), endogenous microglial activators present in senile plaques. $R t$ also significantly inhibited the expression and production of inflammatory and oxidative molecules, including IL- $1 \beta$, tumor necrosis factor- $\alpha$, and nitric oxide, by cultured microglia after treatment with CGA. These effects of $R t$ are considered to be mediated by the secretion of interleukin-10 (IL-10) from microglia, because neutralizing antibodies against IL-10 significantly canceled these effects. To explore the causative components of $R t$ responsible for inducing the secretion of IL-10, the effects of seven components of $R t$ on the IL-10 expression in microglia were examined. Among them, aloe-emodin $(10 \mu \mathrm{M})$ and $(+)$-catechin $(30 \mu \mathrm{M})$ were able to induce the secretion of IL-10 from cultured microglia. Therefore, aloe-emodin and (+)-catechin are deemed responsible for the antineuroinflammatory and antioxidative effects of $R t$ through the secretion of IL-10 from microglia. Accordingly, $R t$ is considered potentially useful for the treatment of $\mathrm{AD}$.
\end{abstract}

\section{Introduction}

There is increasing evidence that chronic neuroinflammation by activated microglia is closely associated with many neurological disorders, including Alzheimer's disease (AD). Furthermore, findings suggest that neuroinflammation mediated by activated microglia plays an essential role in the pathogenesis and progression of $\mathrm{AD}[1,2]$. Recently, it has been demonstrated that neuroinflammation is not a passive system activated by emerging senile plaques and neurofibrillary tangles but instead contributes as much to pathogenesis as do the plaques and tangles themselves [3]. More recently, two research groups have provided evidence that neuroinflammation is not a result of $\mathrm{AD}$ as much as a key driver of the disease $[4,5]$.

Medicinal plants can be considered an important resource for identifying anti-inflammatory agents, as they contain many kinds of natural polyphenols that exert anti-inflammatory and antioxidative activities. There is accumulating evidence indicating that medicinal plants and natural products including ginsenosides from Panax ginseng, curcumin from Curucuma longaI, and resveratrol, a natural polyphenol, have antineuroinflammatory and neuroprotective effects through inhibition of microglial activation 
[6]. Furthermore, we have recently reported that green propolis, a resinous substance by honeybees as a defense against intruders, has both antineuroinflammatory and neuroprotective effects $[7,8]$. Rheum tanguticum $(R t)$, which is endemic to the eastern part of the Qinghai-Tibet Plateau in China, is a well-known traditional medicine with purgation, antibacterial, antipyretic, and hemostatic effects. $R t$ contains twenty compounds including anthraquinones that possess anti-inflammatory effects [9]. However, little information is available about anti-inflammatory and antioxidative activities of $R t$.

Interleukin-10 (IL-10) is known to inhibit the lipopolysaccharide- (LPS-) induced production of several inflammatory mediators, the expression of cytokine receptors, and the expression of major histocompatibility complex II in microglia [10-15]. IL-10 can also inhibit the LPS- or cytokine-induced expression of chemokines and adhesion molecules in microglia $[16,17]$. Furthermore, a peripheral injection with LPS in IL-10-deficient mice causes a prominent cognitive deficit compared with wild-type mice [18]. IL-10 acts through the activation of its receptor (IL-10R). Upon binding, the receptor oligomerizes into a tetramer composed of two ligand-binding subunits (IL-10R1) and two accessory subunits (IL-10R2) that in turn activate an intracellular signaling cascade [19]. Therefore, IL-10 is considered a potent negative autocrine regulator of microglia, as microglia produce IL-10 and possess IL-10R $[11,20]$. Resveratrol, a natural polyphenol first identified as a bioactive compound in 1992, is naturally present in red wine and grapes and has been to exert a neuroprotective effect through its anti-inflammatory and antioxidant effects [21]. Recently, the production and secretion of IL-10 from microglia has shown to be responsible for the anti-inflammatory and antioxidant effects of this agent $[22,23]$. Moreover, it has been also reported that the protective effects of curcumin are IL10 dependent [24].

In the present study, we thus examined the possible antineuroinflammatory and antioxidative effects of $R t$ using the organotypic hippocampal slice cultures and cultured microglia after stimulation with endogenous microglial activators localized in the senile plaques of $\mathrm{AD}$ patients.

\section{Materials and Methods}

2.1. Reagents. Rt was purchased from Qinghai Jinke Tibetan Medicine Pharmaceutical Co., Ltd. (Xining, China). Rt contained seven anthraquinones or glycosides of anthraquinones including chrysophanol, aloe-emodin, physcion, rhein, emodin, chrysophanol-8-O- $\beta$-D-glucopyranoside, and aloeemodin-8-O- $\beta$-D-glucopyranoside. In addition, $R t$ contained two phenylbutanone glucopyranosides (lindleyin and isolindleyin), piceatannol, (+)-catechin, $\beta$-sitosterol, epicatechin-3-O-gallate, and torachrysone-8-O- $\beta$-D-glucopyranoside. The suitable concentration of methanol for cell culture was titrated in order to prevent the interference induced by the methanol solvent. Chromogranin A (CGA, synthetic human CGA286-301) and pancreastatin (PST) were purchased from Peptide Institute (Osaka, Japan). Mouse antiIL-10 neutralizing antibody (IL-10NAb) was purchased from
Abcam (Cambridge, UK). Antibodies against mouse antiinterleukin- $1 \beta$ (IL- $1 \beta$ ), mouse antiphospho-I $\kappa \mathrm{B} \alpha$, rabbit anti-I $\kappa \mathrm{B} \alpha$, and goat antiphospho-signal transducer and activator of transcription 1 (STAT1) were purchased from Santa Cruz Biotechnology (Santa Cruz, CA, USA). Major $R t$ components including chrisophanol, physcion, $\beta$-sitosterol, emodin, aloe-emodin, $(+)$-catechin, and piceatannol were purchased from Abcam (UK). In preliminary experiments, minimum effective dose of either CGA or PST for mRNA expression of proinflammatory mediators in MG6 cells and primary microglia was determined to be $10 \mathrm{nM}$. Therefore, CGA and PST with the concentration of $10 \mathrm{nM}$ were used in this study. On the other hand, three different concentrations $(10,30$, and $100 \mu \mathrm{M})$ of aloe-emodin, $(+)$-catechin, piceatannol, chrisophanol, physcion, $\beta$ sitosterol, and emodin were used.

2.2. Cell Viability Assay. MG6 cells were seeded in 96-well plates $\left(5 \times 10^{3}\right.$ cells/well) overnight [25]. Different concentrations ranging from 5 to $500 \mu \mathrm{g} / \mathrm{ml}$ of $R t$ were treated for $24 \mathrm{~h}$. A cell viability assay was conducted using a cell counting kit (Dojindo, Japan) according to the protocol provided by the manufacturer. The optical density was read at wavelength of $450 \mathrm{~nm}$ with a microplate reader. The cell viability was calculated by dividing the optical density of $R t$-treated group by that of nontreated group. $R t$ up to $10 \mu \mathrm{g} / \mathrm{ml}$ had no significant toxic effect on MG6 cells, therefore $10 \mu \mathrm{g} / \mathrm{ml} R t$ was used in further experiments.

2.3. Organotypic Hippocampal Slice Cultures. Male C57BL/6 mice (10 months of age) were sacrificed and their brains were removed. All animals were treated in accordance with the protocols approved by the animal care and use committee of Kyushu University. Sagittal sections $200 \mu \mathrm{m}$ thick were cut using a vibratome (VT1000S; Wetzlar, Leica), and intact sections were carefully selected under a microscope and incubated in cooled dissection buffer (50\% HEPES-buffered MEM, $1 \%$ penicillin-streptomycin, $10 \mathrm{mM}$ Tris, $\mathrm{pH} 7.2$ ) for $30 \mathrm{~min}$ at $4^{\circ} \mathrm{C}$. The slices were then carefully transferred to 24-well plates containing $0.5 \mathrm{ml}$ of slice culture medium (50\% HEPES-buffered MEM, 25\% heat-inactivated horse serum, $25 \%$ HBSS, $1 \mathrm{mML}$-glutamine, $\mathrm{pH} ; 7.4$ ) and maintained in a cell culture incubator at $37^{\circ} \mathrm{C}, 5 \% \mathrm{CO}_{2}$. One day after preparation, the medium was changed, and $R t$ was applied at $10 \mu \mathrm{g} / \mathrm{ml}$. CGA $(10 \mathrm{nM})$ and PST $(10 \mathrm{nM})$ were added $24 \mathrm{~h}$ after $R t$ treatment. The slices were collected and lysed for Western blotting at $48 \mathrm{~h}$ after treatment with CGA or PST. In some experiments, microglia were depleted from hippocampal slice cultures using saponin coupled to an antibody against Macl (Macl-sap; Advanced Targeting Systems, San Diego, USA). Mac1-sap at $1.3 \mathrm{nM}$ was applied to hippocampal slice cultures $24 \mathrm{~h}$ prior to stimulation with CGA or PST.

2.4. Microglia Cell Culture. The c-myc-immortalized mouse microglial cell line MG6 (Riken Cell Bank, Tsukuba, Japan) was maintained in DMEM supplemented with $100 \mu \mathrm{mol} / \mathrm{L} \beta$-mercaptoethanol, $10 \mu \mathrm{g} / \mathrm{mL}$ of insulin, $1 \%$ penicillin-streptomycin (Invitrogen, Grand Island, NY, 
USA), $4500 \mathrm{mg} / \mathrm{L}$ glucose (Invitrogen), and 10\% FBS according to previously described methods. Primary cultured microglia were isolated from the mixed primary cell cultures obtained from the cerebral cortex of three-day-old C57BL/6 mice according to previously described methods [26].

\subsection{Real-Time Quantitative Polymerase Chain Reaction} ( $q R T-P C R)$. Total RNA was extracted using RNAiso Plus according to the manufacturer's instructions. $1 \mu \mathrm{g}$ of total RNA was used for cDNA synthesis using the QuantiTect Reverse Transcription Kit (Qiagen, Hilden, Germany). After an initial amplification with a denaturation step at $95^{\circ} \mathrm{C}$ for $5 \mathrm{~m}$, followed by $30-40$ cycles of denaturation at $95^{\circ} \mathrm{C}$ for $5 \mathrm{~s}$, annealing at $60^{\circ} \mathrm{C}$ for $10 \mathrm{~s}$, and extension at $72^{\circ} \mathrm{C}$ for $30 \mathrm{~s}$, a final extension at $72^{\circ} \mathrm{C}$ for $5 \mathrm{~m}$ was done upon completion of the cycling steps. The cDNA was amplified in duplicate using a Rotor-Gene SYBR Green RT-PCR Kit (Qiagen) with a Corbett Rotor-Gene RG-3000A Real-Time PCR System. The data were evaluated using the RG-3000A software program (version Rotor-Gene 6.1.93, Corbett, Sydney, Australia). The sequences of primer pairs were described as follows: IL-1 $\beta$ : $5^{\prime}$-CAACCAACAAGTGATATTCTCCATG-3' and $5^{\prime}$-GATCCACACTCTCAGCTGCA-3' ${ }^{\prime}$; inducible nitric oxide synthase (iNOS): $5^{\prime}$-GCCACCAACAATGGCAAC- $3^{\prime}$ and $5^{\prime}$ - CGTACCGGATGAGCTGTGAATT- $3^{\prime}$; TNF- $\alpha: 5^{\prime}-$ ATGGCCTCCCTC TCAGTTC $-3^{\prime}$ and $5^{\prime}$-TTGGTGGTT TGCTACGACGTG-3'; and IL-10: $5^{\prime}$-GACCAGCTGGA CAACATACTGC TAA- $3^{\prime}$ and $5^{\prime}$-GATAAGGATTGGCA ACCCAAGTAA- $3^{\prime}$. For data normalization, an endogenous control (actin) was assessed to control for the cDNA input, and the relative units were calculated by a comparative $\mathrm{Ct}$ method. All qRT-PCR experiments were repeated three times, and the results are presented as the means of the ratios \pm SEM.

2.6. Western Blotting. MG6 were cultured at a density of $5 \times 10^{5}$ cells $/ \mathrm{mL}$. After treatment with $R t(10 \mu \mathrm{g} / \mathrm{ml})$ for $24 \mathrm{~h}$, microglia were treated with CGA $(10 \mathrm{nmol} / \mathrm{L})$ for various time points. The cytosolic samples were collected at various time points. Western blotting was performed with a SDS-PAGE electrophoresis system. $30 \mu \mathrm{g}$ protein samples were resuspended in sample buffer, then electrophoresed on a $15 \%$ or $12 \%$ Tris gel, and then blotted to the PVDF membrane. After blocking, the membranes were incubated at $4^{\circ} \mathrm{C}$ overnight under gentle agitation with each primary antibody: mouse anti-IL- $1 \beta(1: 1000)$, mouse antiphospho-I $\kappa \mathrm{B} \alpha$ (1:1000), rabbit anti- $\mathrm{I} \kappa \mathrm{B} \alpha(1: 1000)$, goat antiphosphoSTAT1 (1:1000), and anti- $\beta$-actin $(1: 1000)$ antibodies overnight at $4^{\circ} \mathrm{C}$. After washing, the membranes were incubated with horseradish peroxidase- (HRP-) labeled antigoat (1:1000; R\&D Systems, Minneapolis, MN, USA), antirabbit (1:1000; Beckman Coulter, Tokyo, Japan), or antimouse (1:1000; Amersham Pharmacia Biotech, Piscataway, NJ, USA) antibodies for $2 \mathrm{~h}$ at $24^{\circ} \mathrm{C}$ and then detected using an enhanced chemiluminescence detection system (ECK kit; Amersham Pharmacia Biotech, Piscataway, NJ, USA) with an image analyzer (LAS-4000; Fuji Photo Film, Tokyo, Japan).
2.7. ELISA. The cytokines IL- $1 \beta$ and IL-10 were measured by enzyme-linked immunosorbent assay (ELISA) kits (R\&D Systems) following the protocol provided by the manufacturer. The absorbance at $450 \mathrm{~nm}$ was determined using a microplate reader.

2.8. Immunostaining. The cultured microglia were fixed with $4 \%$ paraformaldehyde $48 \mathrm{~h}$ after CGA treatment or pretreatment with $R t$. They were then incubated with the mouse antip65 overnight at $4^{\circ} \mathrm{C}$. After washing with PBS, the sections were incubated with donkey antimouse Alexus 488 (1:500; Jackson ImmunoResearch, West Grove, PA, USA), then incubated with Hoechst $(1: 200)$, and mounted in Vectashield antifading medium (Vector Laboratories, Burlingame, CA, USA). Fluorescence images were taken using a confocal laser-scanning microscope (CLSM; 2si Confocal Laser Microscope, Nikon, Tokyo, Japan). The line plot profile was analyzed using Image J.

2.9. $\mathrm{NO}_{2}^{-} / \mathrm{NO}_{3}{ }^{-}$Assay. MG6 were cultured at a density of $5 \times 10^{5}$ cells $/ \mathrm{mL}$. After treatment with $R t(10 \mu \mathrm{g} / \mathrm{L})$ for $24 \mathrm{~h}$, microglia were treated with CGA $(10 \mathrm{nM})$ for $72 \mathrm{~h}$, and the supernatant of the cells was collected. The amounts of $\mathrm{NO}_{2}{ }^{-}$and $\mathrm{NO}_{3}{ }^{-}$were measured by $\mathrm{NO}_{2}{ }^{-} / \mathrm{NO}_{3}{ }^{-}$assay kits (R\&D Systems) following the protocol provided by the manufacturer. The absorbance at $540 \mathrm{~nm}$ was determined using a microplate reader.

2.10. Statistical Analyses. The data are represented as the mean \pm standard error of the mean.

A two-tailed unpaired Student's $t$-test and a one-way analysis of variance (ANOVA) with a post hoc Tukey's test were performed for the statistical analyses by the GraphPad Prism 7 Software package (GraphPad Software Inc., San Diego, CA, USA). A value of $P<0.05$ was considered to indicate statistical significance.

\section{Results}

3.1. Inhibitory Effects of Rt on the CGA- and PST-Induced Expression of IL- $\beta$ in Organotypic Hippocampal Slice Cultures. The viability of MG6 cells was examined using the CCk- 8 assay at $24 \mathrm{~h}$ after treatment with $R t$ with the concentration ranging from 5 to $500 \mu \mathrm{g} / \mathrm{ml}$. Rt up to $10 \mu \mathrm{g} / \mathrm{ml} \mathrm{had}$ no significant toxic effect on MG6 cells (Figure 1). CGA and PST with the minimum effective dose determined in preliminary experiments were used to activate microglia, as they are potent endogenous microglial activators and localize in the senile plaques of AD patients [27-29].

To elucidate the possible antineuroinflammatory effects, the effects of $R t(10 \mu \mathrm{g} / \mathrm{ml})$ on the expression of IL- $\beta$ in organotypic hippocampal slice cultures were examined by Western blotting. The mean protein level of IL- $1 \beta$ was significantly increased in the organotypic hippocampal slice cultures at $48 \mathrm{~h}$ after stimulation with CGA (10 nM). Rt significantly suppressed the mean protein level of IL- $1 \beta$ in CGA-stimulated organotypic hippocampal slice cultures (Figure 2(a)). PST (10 nM) also significantly increased the mean protein level of IL- $\beta$ in the organotypic hippocampal slice cultures to a similar extent as CGA. Furthermore, $R t$ 


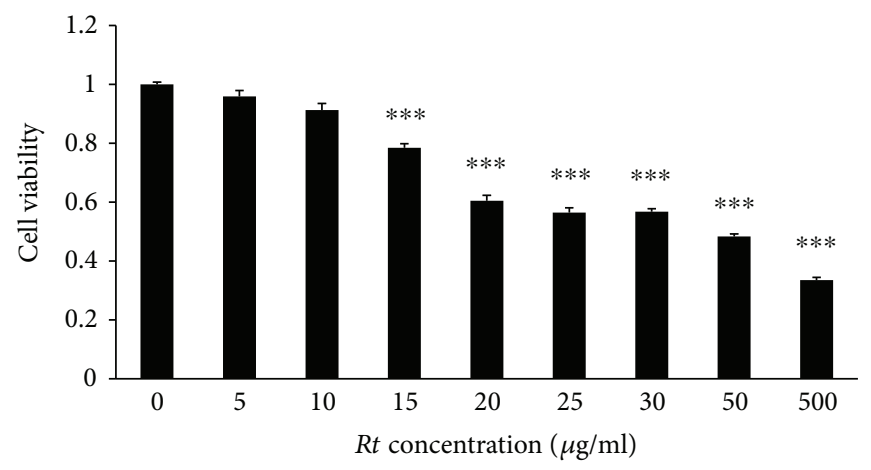

FIGURE 1: The cell viability of MG6 cells at $24 \mathrm{~h}$ after treatment with different dose of $R t$ by using a cell counting kit- 8 . The results represent the mean \pm SEM of four independent experiments. The asterisks indicate a statistically significant difference from the value in untreated cells $\left({ }^{* * *} P<0.001\right)$.
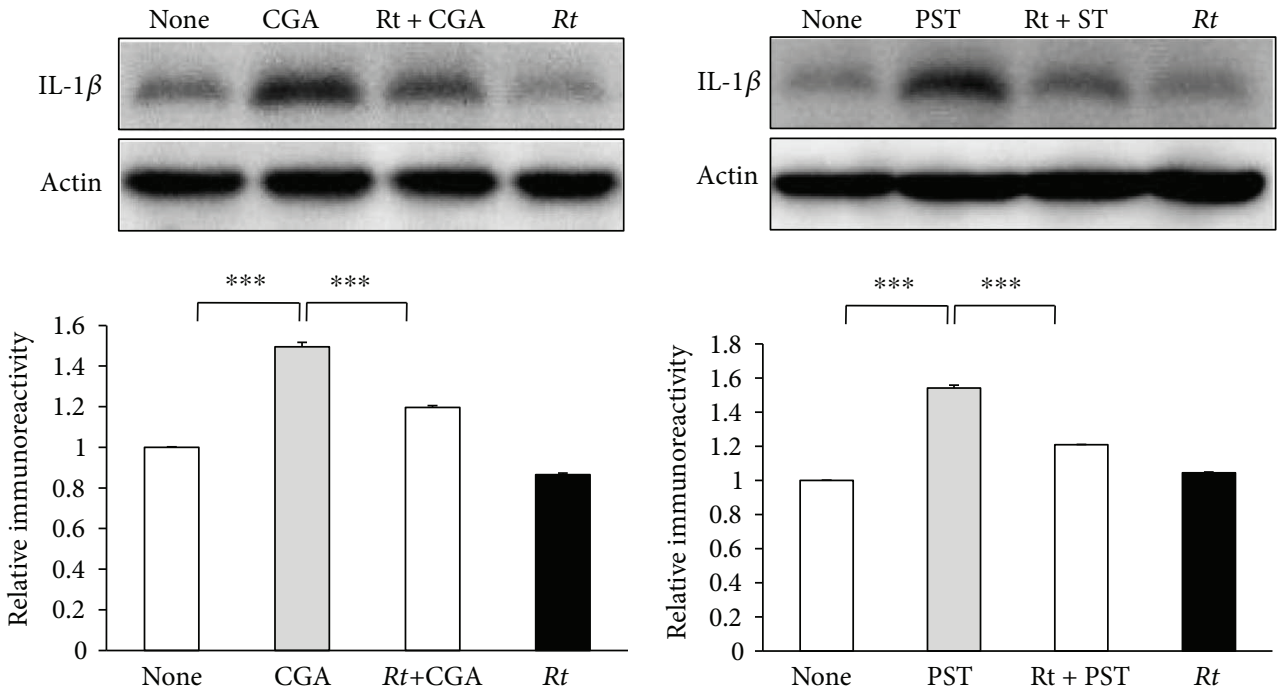

(a)

(b)

FIGURE 2: Inhibitory effects of Rt on CGA- or PST-induced IL- $1 \beta$ production in the hippocampal slice cultures. (a) The effect of $R t$ (10 $\mu \mathrm{g} / \mathrm{ml}$ ) on the protein level of IL-1 $\beta$ after stimulation with CGA using Western blotting. The results represent the mean \pm SEM of three independent experiments. The asterisks indicate a statistically significant difference from the indicated value $\left({ }^{* * *} P<0.001\right)$. (b) The effect of $R t(10 \mu \mathrm{g} / \mathrm{ml})$ on the protein level of IL- $1 \beta$ after stimulation with PST. The results represent the mean \pm SEM of three independent experiments. The asterisks indicate a statistically significant difference from the indicated value $\left({ }^{* * *} P<0.001\right)$.

significantly suppressed the PST-induced IL- $1 \beta$ production (Figure 2(b)). Therefore, CGA286-301 may be an active component of PST, as CGA used in this study was human CGA286-301, which includes the carboxy-terminal of PST. In contrast, both CGA and PST failed to significantly increase the mean protein level of IL-1 $\beta$ in the Mac1-sap treated hippocampal slice cultures (Figures 3(a) and 3(b)), suggesting that microglia are responsible for the IL- $1 \beta$ production after treatment with CGA or PST.

\subsection{Inhibitory Effects of Rt on the CGA-Induced Expression} of Proinflammatory and Oxidative Mediators in Microglia. To elucidate the possible anti-inflammatory and antioxidative roles, effects of $R t(10 \mu \mathrm{g} / \mathrm{ml})$ on the expression of proinflammatory mediators by microglia were examined at the transcriptional level using quantitative RT-PCR. Rt significantly suppressed the mean basal mRNA expression levels of IL- $1 \beta$ and iNOS, but not TNF- $\alpha$, in nonstimulated MG6 cells (Figures 4(a)-4(c)). The mean mRNA expression levels of TNF- $\alpha$, IL- $1 \beta$, and iNOS was significantly increased in MG6 cells at $24 \mathrm{~h}$ after stimulation with CGA $(10 \mathrm{nM})$. Rt significantly suppressed the mean mRNA expression levels of TNF- $\alpha$, IL- $1 \beta$, and iNOS in CGA-stimulated MG6 cells (Figures 5(a)-5(c)). Furthermore, the secretion of IL- $1 \beta$ and NO metabolites in the culture medium of MG6 cells was assessed by an ELISA and $\mathrm{NO}_{2}{ }^{-} / \mathrm{NO}_{3}{ }^{-}$assay, respectively. The mean levels of IL- $1 \beta$ and $\mathrm{NO}_{2}{ }^{-} / \mathrm{NO}_{3}{ }^{-}$were significantly increased in the culture medium of MG6 cells at $24 \mathrm{~h}$ after treatment with CGA. $R t$ also significantly decreased the mean levels of IL$1 \beta$ and $\mathrm{NO}_{2}^{-} / \mathrm{NO}_{3}{ }^{-}$in the culture medium of MG6 cells (Figures 5(d) and 5(e)). 


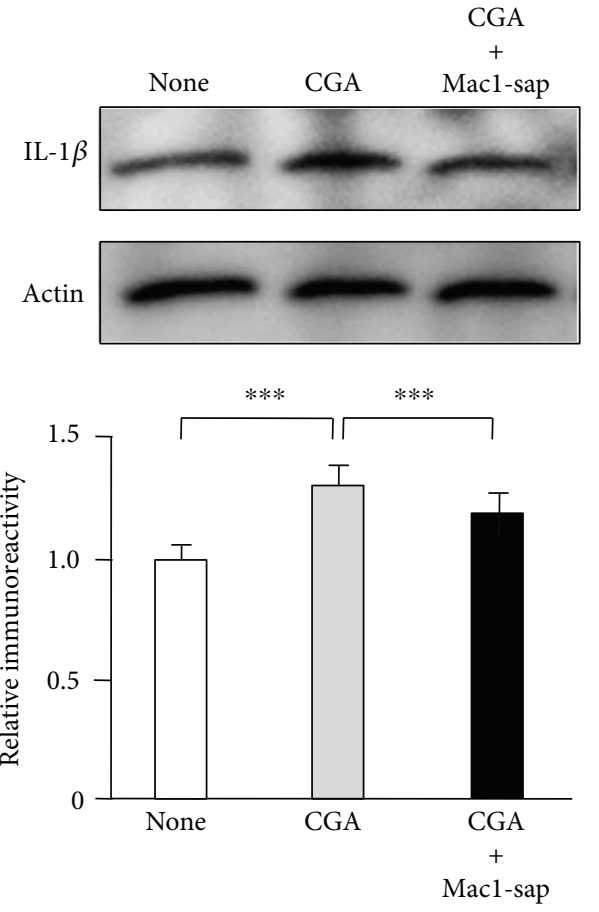

(a)
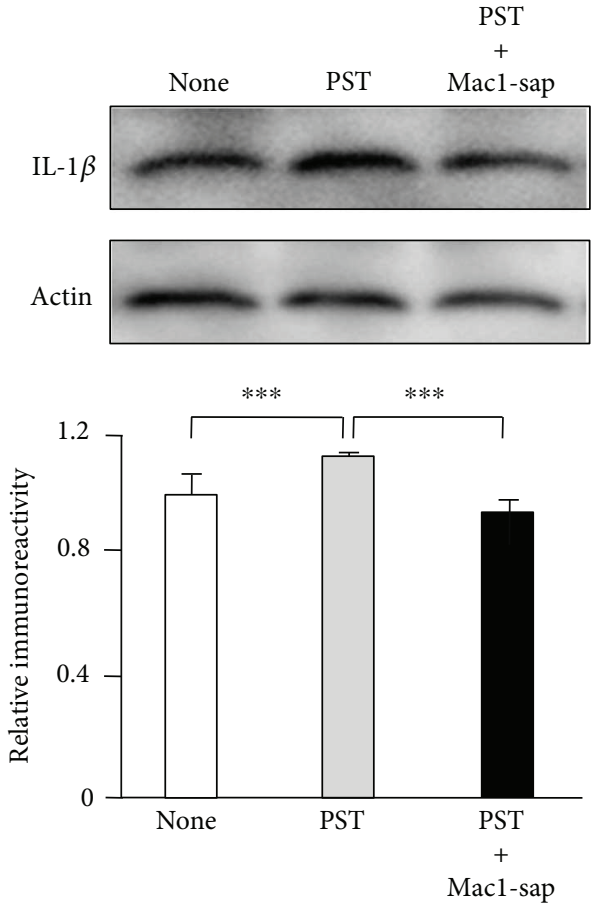

(b)

FIGURE 3: The failure of IL-1 $\beta$ production after treatment with CGA or PST in the microglia-depleted hippocampal slice cultures using Mac1sap. (a) The effect of CGA on the protein level of IL-1 $\beta$ in the nontreated and Mac1-sap-treated cultures. The results represent the mean \pm SEM of three independent experiments. The asterisks indicate a statistically significant difference from the indicated value $\left({ }^{* * *} P<0.001\right)$. (b) The effect of PST on the protein level of IL- $1 \beta$ in the nontreated and Mac1-sap-treated culture. The results represent the mean \pm SEM of three independent experiments. The asterisks indicate a statistically significant difference from the indicated value $\left({ }^{* * *} P<0.001\right)$.

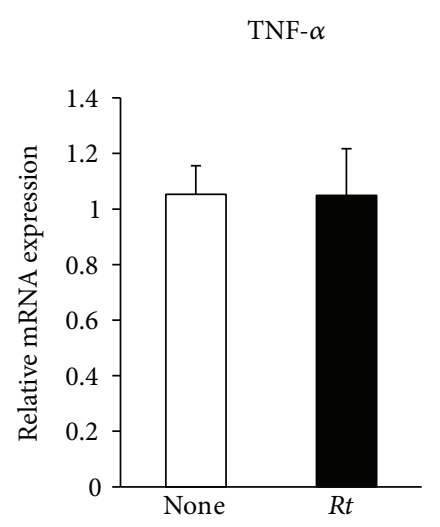

(a)

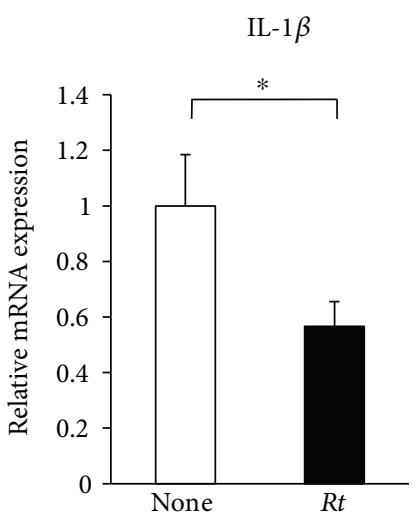

(b)

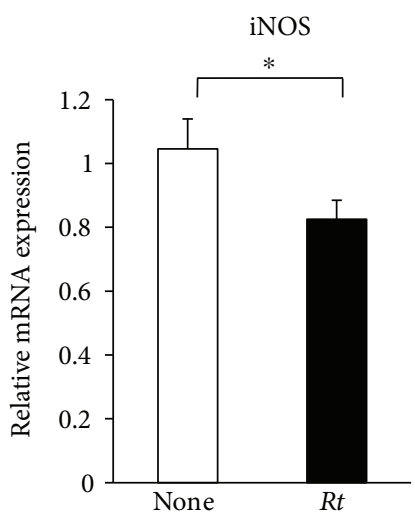

(c)

FIGURE 4: The inhibitory effects of $R t$ on the CGA-induced expression of proinflammatory and oxidative mediators in microglia. The effect of $R t(10 \mu \mathrm{g} / \mathrm{ml})$ on the basal mRNA expression of TNF- $\alpha$ (a), IL-1 $\beta$ (b), and iNOS (c) in the nonstimulated MG6 cells. Each column and bar represents the mean \pm SEM $\left(n=4\right.$ each). The asterisks indicate a statistically significant difference from the indicated value $\left({ }^{*} P<0.05\right)$.

RT-PCR and ELISA were also performed to determine whether or not Rt was able to regulate the production of the anti-inflammatory cytokine IL-10. CGA $(10 \mathrm{nM})$ alone failed to increase the mean mRNA level of IL-10, whereas the combination of CGA and $R t$ significantly increased the mean mRNA level of IL-10 (Figure 5(f)), suggesting that $R t$ was able to upregulate the expression of IL-10. As expected, the mean mRNA expression of IL-10 in MG6 cells was significantly increased at $12 \mathrm{~h}$ and peaked at $24 \mathrm{~h}$ after treatment with $R t$ alone at $5 \mu \mathrm{g} / \mathrm{ml}$ (Figure 6(a)). Rt was able to significantly increase the mean mRNA expression level of IL-10 in MG6 cells at $24 \mathrm{~h}$ after treatment at $>5 \mu \mathrm{g} / \mathrm{ml}$ (Figure 6(b)) without affecting the expression of IL-1 $\beta$ (data not shown). In contrast, the mean level of IL-10 in the culture medium of MG6 cells significantly increased at $24 \mathrm{~h}$ and peaked at $48 \mathrm{~h}$ after treatment of Rt at $5 \mu \mathrm{g} / \mathrm{ml}$ (Figure 6(c)). The mean level of IL-10 secretion was significantly increased at $48 \mathrm{~h}$ after treatment with $R t$ at $>5 \mu \mathrm{g} / \mathrm{ml}$ in the culture medium 


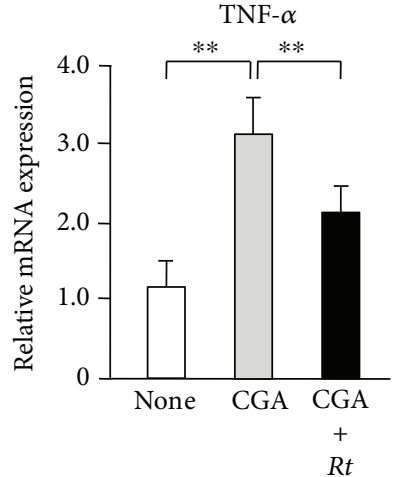

(a)

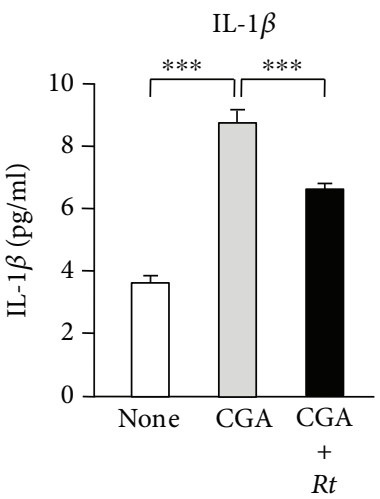

(d)

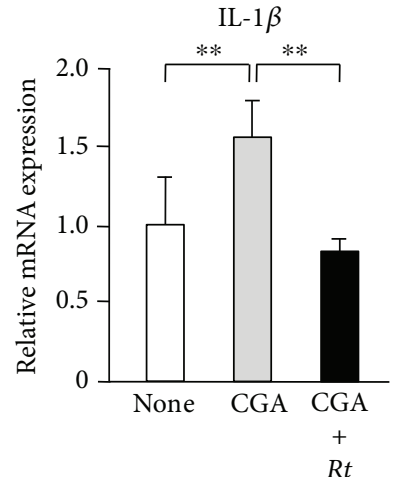

(b)

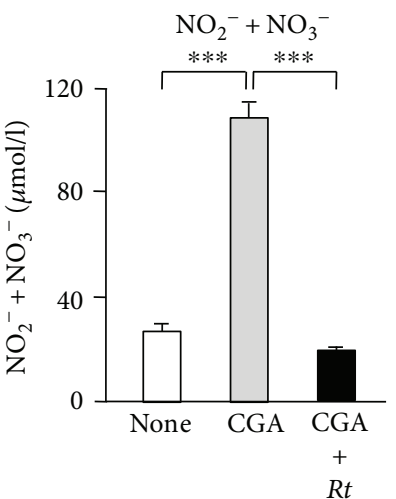

(e)

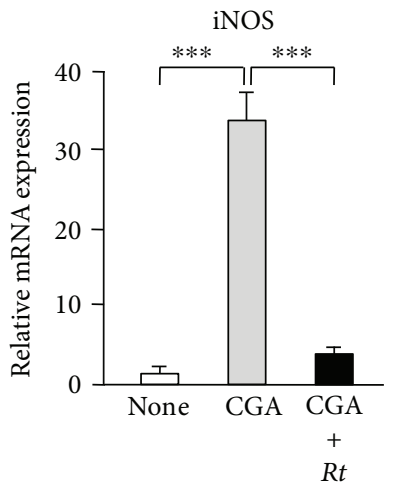

(c)

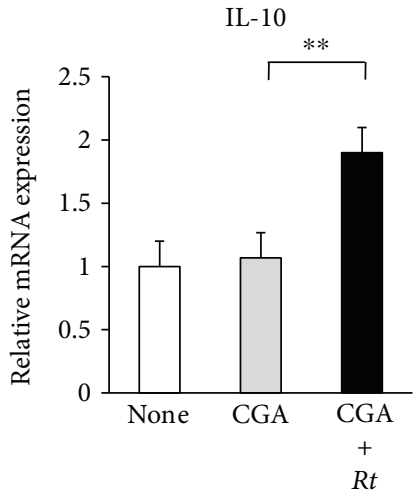

(f)

FIGURE 5: The inhibitory effects of $R t$ on the CGA-induced expression of proinflammatory and oxidative mediators in microglia. (a-c) The effect of $R t(10 \mu \mathrm{g} / \mathrm{ml})$ on the mRNA expression of TNF- $\alpha$ (a), IL-1 $\beta$ (b), and iNOS (c) in the MG6 cells after stimulation with CGA. Each column and bar represents the mean \pm SEM $(n=4$ each). The asterisks indicate a statistically significant difference from the indicated value $\left({ }^{* *} P<0.01,{ }^{* * *} P<0.001\right)$. (d) The secretion of IL-1 $\beta$ in the MG6 cells $96 \mathrm{~h}$ after stimulation with CGA with or without pretreatment with $R t$. The results represent the mean \pm SEM of three independent experiments. The asterisks indicate a statistically significant difference from the indicated value $\left({ }^{* *} P<0.001\right)$. (e) The examination of NO metabolites in the culture medium of MG6 cells $72 \mathrm{~h}$ after stimulation with CGA with or without pretreatment with $R t$ by $\mathrm{NO}_{2}{ }^{-} / \mathrm{NO}_{3}{ }^{-}$assay. The results represent the mean $\pm \mathrm{SEM}$ of three independent experiments. The asterisks indicate a statistically significant difference from the indicated value. $\left({ }^{* * *} P<0.001\right)$. (f) The effect of $R t(10 \mu \mathrm{g} / \mathrm{ml})$ on the mRNA expression of IL-10 in the MG6 cells after stimulation with CGA. The results represent the mean \pm SEM of four independent experiments. The asterisks indicate a statistically significant difference from the indicated value $\left({ }^{* *} P<0.01\right)$.

of both MG6 cells and primary cultured murine microglia (Figure 6(d)). Of note, the mean level of IL-10 in the culture medium of primary cultured microglia $(200 \mathrm{pg} / \mathrm{mL})$ was more than tenfold greater than that of MG6 cells $(14 \mathrm{pg} / \mathrm{mL})$ after treatment with Rt $(10 \mu \mathrm{g} / \mathrm{mL})$.

3.3. Possible Role of IL-10 in the Anti-Inflammatory Effects of Rt on CGA-Stimulated Microglia. To investigate the involvement of IL-10 in the anti-inflammatory effects of $R t$ $(10 \mu \mathrm{g} / \mathrm{ml})$ on inflammatory responses of microglia, we evaluated the effects of IL-10NAb on the Rt-mediated inhibition of the TNF- $\alpha$ and IL-1 $\beta$ expression in CGA-stimulated MG6 cells. IL-10NAb inhibited the mean mRNA expression of TNF- $\alpha$ and IL- $1 \beta$ in CGA-stimulated MG6 cells in the presence of $R t$ (Figures 7(a) and 7(b)). There was no significant difference between the mean percentage recovery from $R t$-induced inhibition of TNF- $\alpha$ and IL- $1 \beta$ mRNA expression after treatment with IL-10NAb (66.7\% for TNF- $\alpha$ and IL-1 $\beta$ for $63.6 \%)$. These observations strongly suggest that
IL-10 plays a critical role in the anti-inflammatory property of $R t$ in microglia.

3.4. Effects of Rt on the Nuclear Factor (NF)- $\kappa B$ and STAT1 Activation Pathways in CGA-Stimulated Microglia. The effects of $R t$ on the nuclear translocation of p65 induced by treatment with CGA were examined. $R t(10 \mu \mathrm{g} / \mathrm{ml})$ significantly inhibited the CGA-induced nuclear translocation of p65 in MG6 cells (Figure 8(a)). When IL-10 was neutralized, the CGA-induced nuclear translocation of p65 in MG6 cells returned to levels in the absence of Rt (Figure 8(a)). These observations clearly show that $R t$ can inhibit CGA-induced activation of the NF- $\kappa$ B pathway in MG6 cells through production of IL-10.

The activation of NF- $\kappa \mathrm{B}$ and STAT1 pathways were further examined after treatment with CGA $(10 \mathrm{nM})$ in MG6 cells by immunoblotting, as these two signaling pathways are required for the production of TNF- $\alpha$, IL- $1 \beta$, and NO. The mean levels of phospho-I $\kappa \mathrm{B} \alpha$ and phospho- 


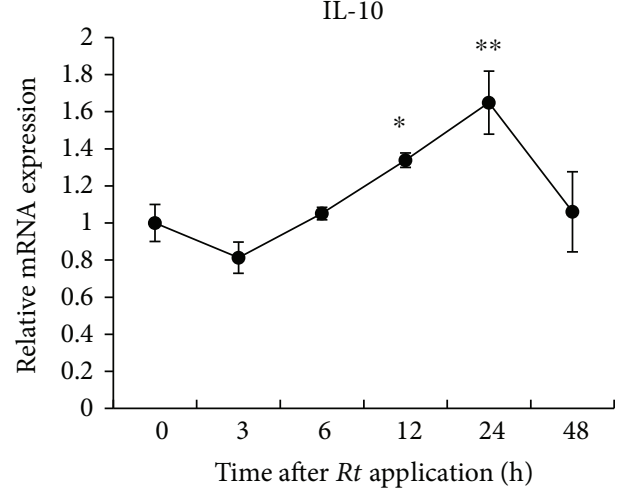

(a)

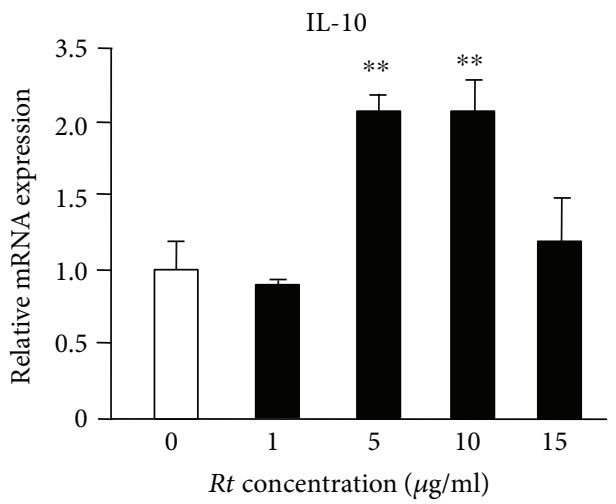

(b)

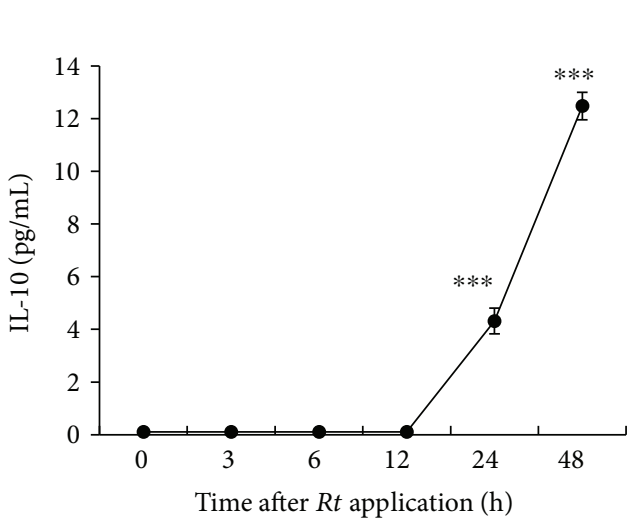

(c)

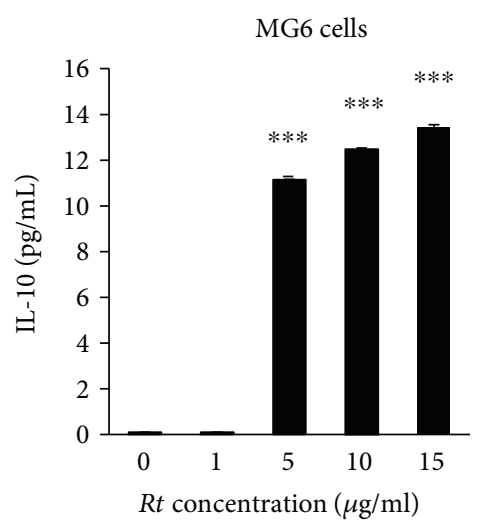

(d)

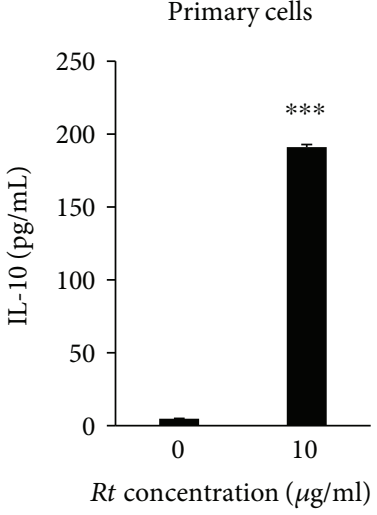

(e)

FIGURE 6: The capable regulation of IL-10 by $R t$ in MG6 cells and primary cultured microglia. (a) The mRNA changes of IL-10 at different time points after treatment with $R t(10 \mu \mathrm{g} / \mathrm{ml})$. The results represent the mean \pm SEM of three independent experiments. The asterisks indicate a statistically significant difference from the value at the start of experiments $(0 \mathrm{~h})\left({ }^{*} P<0.05,{ }^{* *} P<0.01\right)$. (b) The mRNA changes of IL-10 $24 \mathrm{~h}$ after treatment with different doses of $R t$. The results represent the mean \pm SEM of three independent experiments. The asterisks indicate a statistically significant difference from the value in untreated cells $\left({ }^{* *} P<0.01\right)$. (c) The secretion of IL-10 in the cultured medium of MG6 cells at different time points after treatment with $R t(10 \mu \mathrm{g} / \mathrm{ml})$. The results represent the mean \pm SEM of three independent experiments. The asterisks indicate a statistically significant difference from the value at the start of experiments $(0 \mathrm{~h})\left({ }^{* *} P<0.001\right)$. (d) The secretion of IL-10 in the cultured medium of MG6 cells $24 \mathrm{~h}$ after treatment with different doses of Rt. The results represent the mean \pm SEM of three independent experiments. The asterisks indicate a statistically significant difference from the value in untreated cells $\left({ }^{* * *} P<0.001\right)$. (e) The secretion of IL-10 in the cultured medium of primary cultured microglia $24 \mathrm{~h}$ after treatment with $R t(10 \mu \mathrm{g} / \mathrm{ml})$. The results represent the mean \pm SEM of three independent experiments. The asterisks indicate a statistically significant difference from the value in untreated cells $\left({ }^{* * *} P<0.001\right)$.

STAT1 were significantly increased in MG6 cells after treatment with CGA at $10 \mathrm{~min}$ and $3 \mathrm{~h}$, respectively (Figures 8(b) and 9(a)). Rt at $10 \mu \mathrm{g} / \mathrm{ml}$ significantly decreased the mean levels of phospho-I $\kappa \mathrm{B} \alpha$ (Figure $8(\mathrm{c})$ ) and phospho-STAT1 (Figure 9(b)) in CGA-stimulated MG6 cells. Furthermore, the neutralization of IL-10 using IL$10 \mathrm{NAb}$ significantly inhibited the mean levels of phospho$\mathrm{I} \kappa \mathrm{B} \alpha$ (Figure $8(\mathrm{c})$ ) and phospho-STAT1 (Figure 9(b)) in CGA-stimulated MG6 cells in the presence of Rt. These observations suggest that IL-10 plays a critical role in the $R t$-induced anti-inflammatory antioxidative effects through the suppression of NF- $\kappa$ B and STAT1 activation pathways.

\subsection{Possible Components of Rt Responsible for the Production} of IL-10 by Microglia. Finally, to explore the components of $R t$ responsible for the production of IL-10 in microglia, RTPCR was performed to examine the effects of major components of $R t$ including on the mRNA expression in MG6 cells. Effects of three different concentrations (10, 30, and $100 \mu \mathrm{M}$ ) of major $R t$ components including chrisophanol, physcion, $\beta$-sitosterol, emodin, aloe-emodin, (+)-catechin, and piceatannol were examined at $24 \mathrm{~h}$ on the mRNA expression of IL-10 in MG6 cells. Among the major components of $R t$, three components, namely, aloe-emodin, (+)-catechin, and piceatannol, were found to significantly increase the mRNA expression of IL-10 in MG6 cells at $24 \mathrm{~h}$ after treatment (Figure 10(a)). The minimum effective doses of aloe-emodin, $(+)$-catechin, and piceatannol were determined to be 10,30 , and $100 \mu \mathrm{M}$, respectively. In contrast, chrisophanol, physcion, $\beta$-sitosterol, or emodin at concentrations up to $100 \mu \mathrm{M}$ had no effect on the mRNA expression of IL-10 in MG6 cells.

Then, effects of aloe-emodin, (+)-catechin, and piceatannol with the most effective doses on the secretion of IL-10 


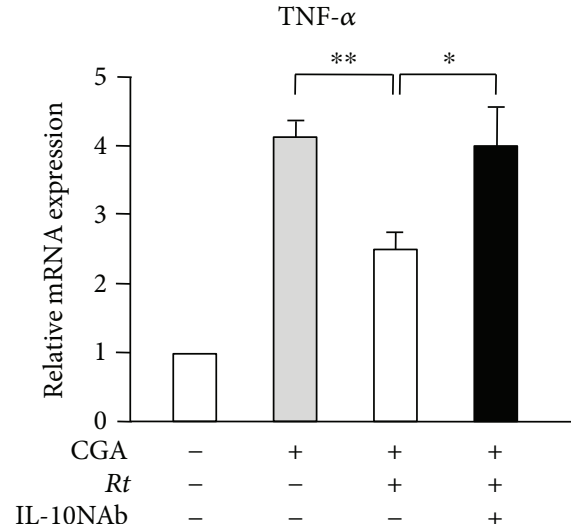

(a)

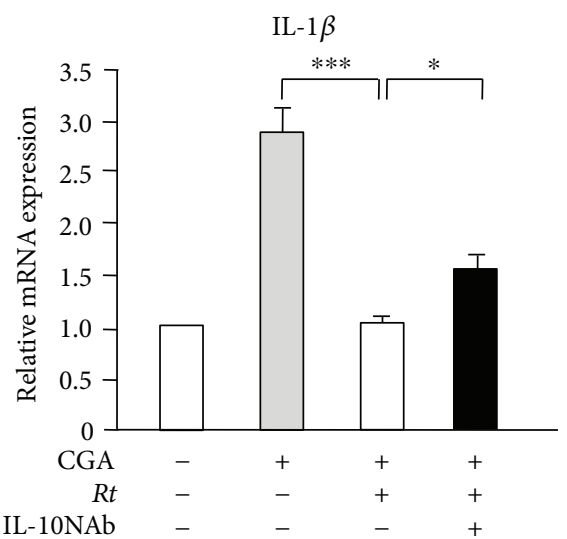

(b)

Figure 7: Possible role of IL-10 in the anti-inflammatory effects of $R t$ on CGA-stimulated microglia. (a, b) The mRNA changes of TNF- $\alpha$ (a) and IL-1 $\beta$ (b) of CGA stimulated MG6 cells in the presence or absence of Rt $(10 \mu \mathrm{g} / \mathrm{ml})$ and IL-10 neutralizing antibody (IL-10NAb). The results represent the mean \pm SEM of three independent experiments. The asterisks indicate a statistically significant difference from the indicated value $\left({ }^{*} P<0.05,{ }^{* *} P<0.01,{ }^{* * *} P<0.001\right)$.

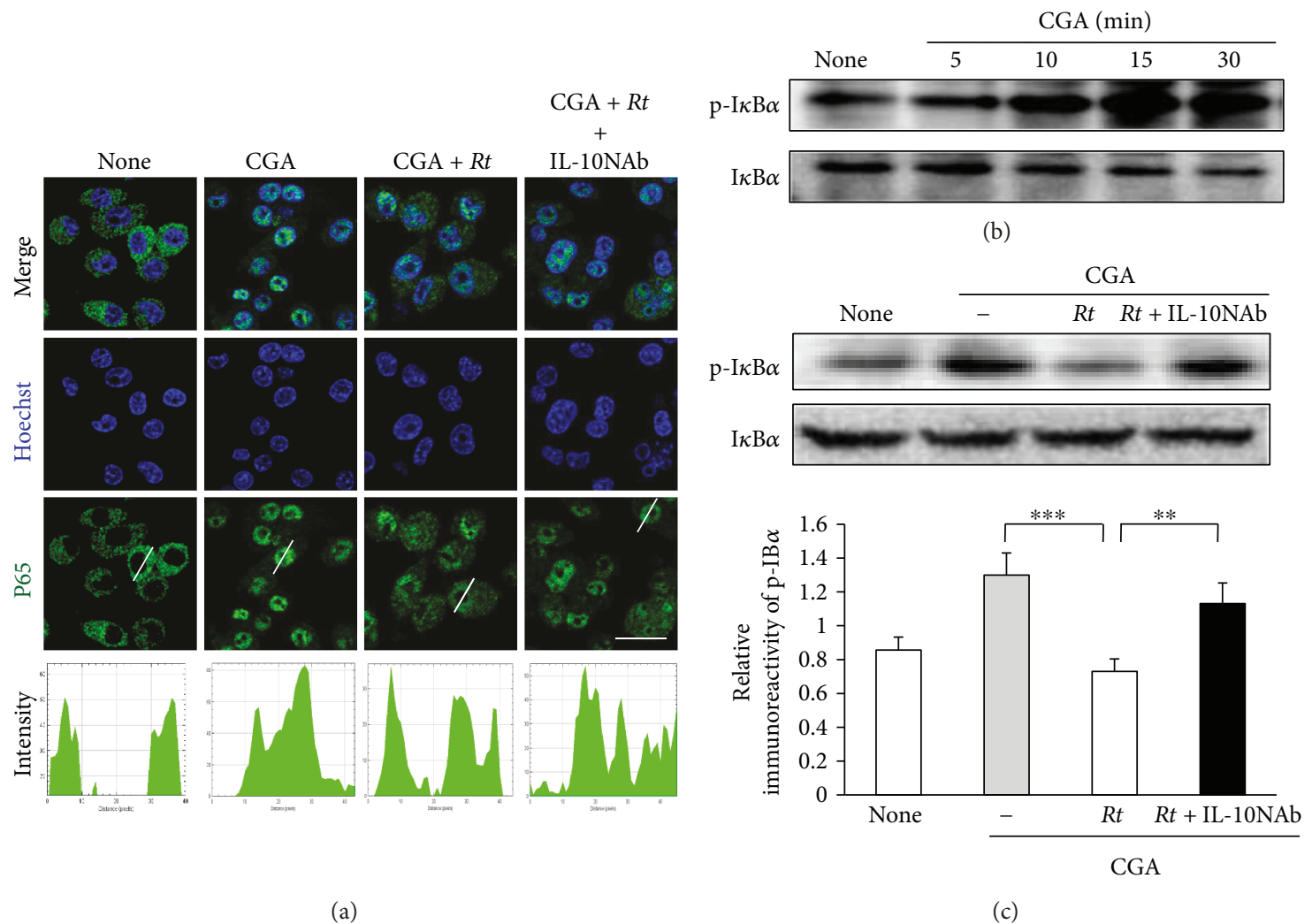

(a)

(c)

FIGURE 8: Effects of Rt on the NF- $\kappa$ B activation pathways in CGA-stimulated microglia. (a) Immunofluorescence CLMS images indicating the nuclear translocation of p65 (green) in MG6 cells with Hoechst-stained nuclei (blue) at $24 \mathrm{~h}$ after stimulation with CGA (10 nM) in the presence or absence of $R t(10 \mu \mathrm{g} / \mathrm{ml})$ and IL-10NAb. Scale bar, $15 \mu \mathrm{m}$. The typical cells were analyzed by line plot profile to show the cytosol and nuclear location of p65. (b) The protein expression of phospho-I $\kappa \mathrm{B} \alpha$ at different time points after stimulation with CGA. (c) The protein expression of phospho-I $\kappa \mathrm{B} \alpha$ in MG6 cells 30 min after CGA stimulation in the presence or absence of Rt (10 $\mu \mathrm{g} / \mathrm{ml})$ and IL$10 \mathrm{NAb}$ and the quantitative analyses of the immunoblotting for phospho- $\mathrm{I} \kappa \mathrm{B} \alpha$. The results represent the mean $\pm \mathrm{SEM}$ of four independent experiments. The asterisks indicate a statistically significant difference from the indicated value $\left({ }^{* *} P<0.01,{ }^{* * *} P<0.001\right)$.

from MG6 cells and primary cultured microglia were examined at three different experimental time points $(24,48$, and $72 \mathrm{~h}$ ). Figure 10(b) showed the mean amounts of IL-10 secreted in the culture medium of MG6 cells and primary cultured microglia after treatment of aloe-emodin and $(+)$-catechin with the minimum effective doses at the most effective experimental time points. On the other hand, piceatannol $(100 \mu \mathrm{M})$ failed to secrete IL-10 even at $72 \mathrm{~h}$ after 


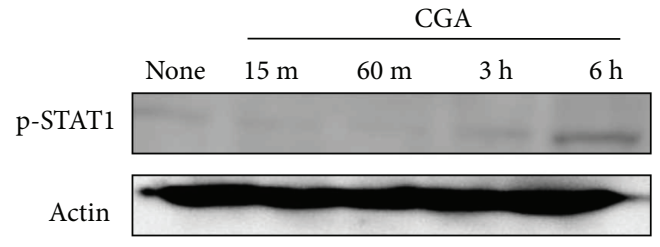

(a)
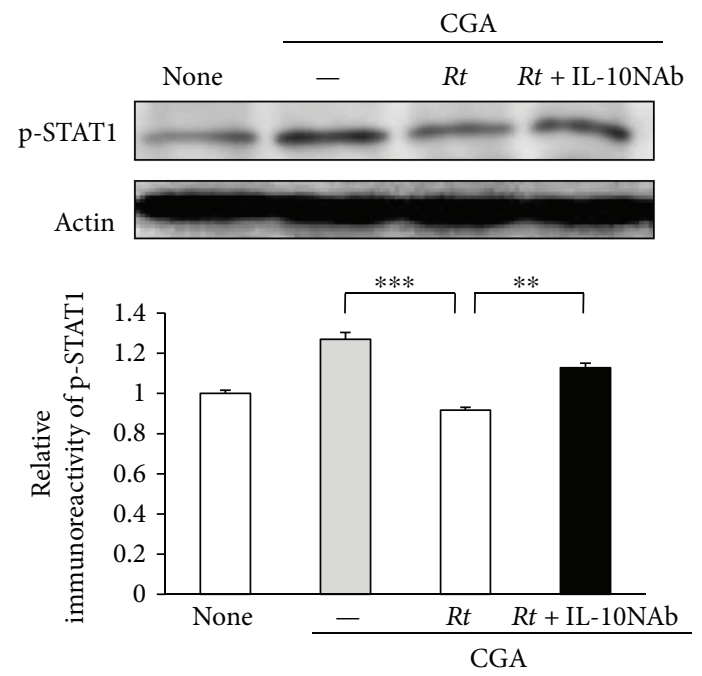

(b)

FIGURE 9: Effects of $R t$ on the STAT1 activation pathways in CGAstimulated microglia. (a) The protein expression of phospho-STAT1 at different time points after stimulation with CGA. (b) The protein expression of phospho-STAT1 in MG6 cells $6 \mathrm{~h}$ after CGA stimulation in the presence or absence of $R t(10 \mu \mathrm{g} / \mathrm{ml})$ and IL$10 \mathrm{NAb}$ and the quantitative analyses of the immunoblotting for phospho-STAT1. The results represent the mean \pm SEM of four independent experiments. The asterisks indicate a statistically significant difference from the indicated value $\left({ }^{* *} P<0.01,{ }^{* * *} P<\right.$ $0.001)$.

treatment. Of note, the mean level of IL-10 in the culture medium of primary cultured microglia was approximately tenfold greater than that of MG6 cells.

\section{Discussion}

In the present study, we demonstrated the antineuroinflammatory effects of $R t$ in CGA-stimulated organotypic hippocampal slice cultures, MG6 cells, and primary cultured microglia. Rt with the concentration of $10 \mu \mathrm{g} / \mathrm{mL}$ significantly suppressed the CGA-induced production of IL- $1 \beta$ in the organotypic hippocampal cultures. $R t$ at $>5 \mu \mathrm{g} / \mathrm{mL}$ also significantly suppressed the CGA-induced expression of TNF- $\alpha$, IL- $1 \beta$, and NO, major molecules produced by neurotoxic microglia. Furthermore, we demonstrated that $R t$ alone was able to upregulate IL-10 at both the mRNA and protein levels, without the upregulation of proinflammatory and oxidative molecules. When IL-10 was neutralized, the mean expression levels of TNF- $\alpha$ and IL- $1 \beta$ returned to the levels observed in the absence of $R t$. These observations indicate that $R t$ may act as a neuroprotective agent during neuroinflammation through inducing the production and secretion of IL-10, a potent negative autocrine regulator of microglia. More recently, IL-10 has been reported to alter macrophage function by promoting the clearance of damaged mitochondria and modulating cellular metabolism to inhibit inflammation [30]. Therefore, $R t$ may increase the capacity of microglia to produce IL-10 through enhanced clearance of damaged mitochondria. In this regard, Rt may act as a polarizing agent in microglia, favoring the shifting towards M2-like phenotype, more efficient as IL10 producer.

The activation of the NF- $\kappa \mathrm{B}$ and STAT1 signaling pathways is considered to play a critical role in the polarization of microglia in the neurotoxic phenotype, as NF- $\kappa \mathrm{B}$ and STAT1 are transcription factors required for the production of TNF- $\alpha$, IL- $1 \beta$, and NO. The Rt-induced inhibition of the $\mathrm{NF}-\kappa \mathrm{B}$ and STAT1 signaling pathways activated in CGAstimulated microglia was inhibited by neutralizing antibody against IL-10. These observations suggest that the $R t$-induced production of IL-10 is responsible for the anti-inflammatory and antioxidative effects of $R t$ in activated microglia through the inhibition of the NF- $\kappa \mathrm{B}$ and STAT1 signaling pathways. Of further note, the mean level of IL-10 in the culture medium of primary cultured microglia $(200 \mathrm{pg} / \mathrm{mL})$ was approximately seventeenfold greater than that of MG6 cells $(10-14 \mathrm{pg} / \mathrm{mL})$. MG6 cells are a mouse microglial cell line immortalized by a replication-deficient retroviral vector containing the human c-myc gene. Therefore, the cMYC expression in microglia may result in an increased production of proinflammatory mediators and decreased production of IL- 10 .

We next examined the effects of seven components of $R t$, including aloe-emodin, (+)-catechin, natannol, chrisophanol, physcion, $\beta$-sitosterol, and emodin, on the increased mRNA expression of IL-10 in microglia. Among them, aloe-emodin and (+)-catechin were able to induce the secretion of IL-10 from microglia. On the other hand, there was a discrepancy between mRNA expression and secretion of IL10 following treatment with piceatannol. After mRNA expression, the secretion of IL-10 could be affected by many steps including translation, posttranslational modification and secretion. The present study does not allow us to exclude any of these steps.

$(+)$-Catechin is a naturally occurring polyphenolic compound that has been shown to have anti-inflammatory, antioxidant, and free radical-scavenging properties in vitro. $(+)$-Catechin has been shown to decrease the production of the proinflammatory cytokines, including IL- $1 \beta$ and TNF$\alpha$, and to enhance the production of the anti-inflammatory cytokine IL-10. (+)-Catechin suppresses the production of proinflammatory mediators by mouse microglia BV-2 cells and mitigation of NF- $\kappa \mathrm{B}$ through intracellular signaling cascades, including Akt, extracellular-signal-regulated kinase, p38 mitogen-activated protein kinase, and AMP-activated protein kinase [31]. In contrast, aloe-emodin is a major anthraquinone in aloe plants that contains a polyphenolic structure. Aloe-emodin has been also shown to suppress the LPS-induced production of $\mathrm{NO}$ and prostaglandin $\mathrm{E}_{2}$ in mouse macrophage RAW 264.7 cells [32]. Therefore, 


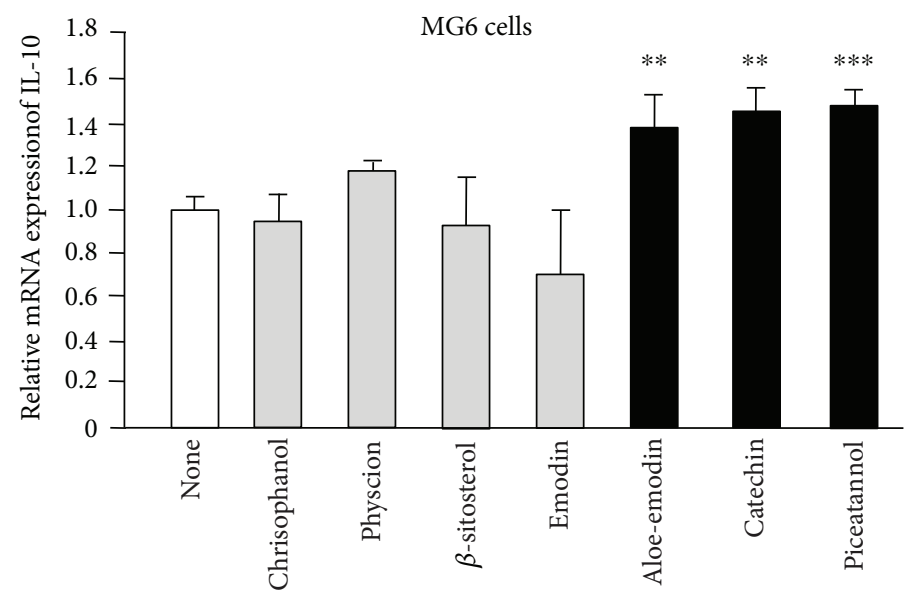

(a)

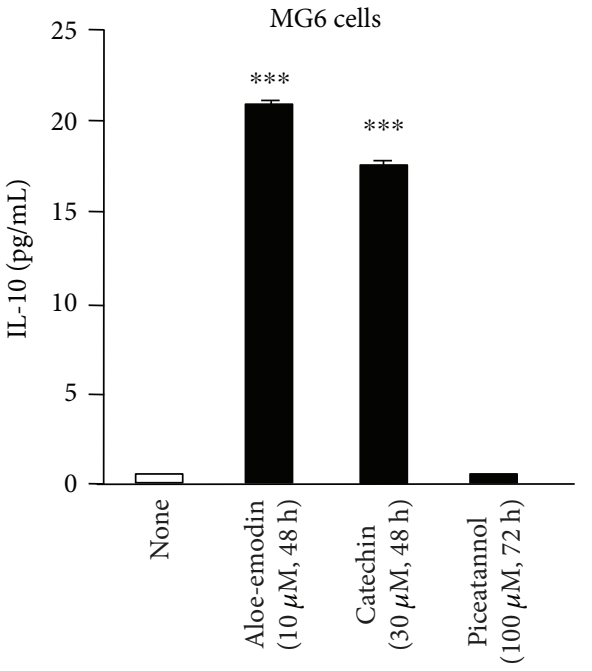

(b)

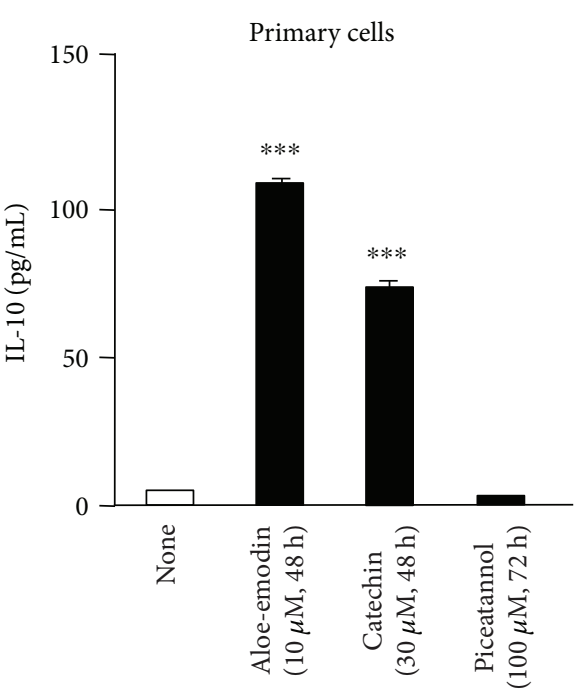

(c)

FIGURE 10: Possible components of Rt responsible for the production of IL-10 in microglia. (a) The change in the mRNA of IL-10 in MG6 cells $24 \mathrm{~h}$ after treatment with components of $R t$, including chrisophanol, physcion, $\beta$-sitosterol, emodin, aloe-emodin, $(+)$-catechin, and piceatannol. The results show the relative mRNA expression of IL-10 after treatment with aloe-emodin $(10 \mu \mathrm{M}),(+)$-catechin $(30 \mu \mathrm{M})$, and piceatannol $(100 \mu \mathrm{M})$ with the minimum effective doses, which were determined after treatment with three different doses (10, 30 , and $100 \mu \mathrm{M})$ for $24 \mathrm{~h}$. On the other hand, chrisophanol, physcion, $\beta$-sitosterol, and emodin with the concentration of $100 \mu \mathrm{M}$ were applied for $24 \mathrm{~h}$. The results represent the mean \pm SEM of three independent experiments. The asterisks indicate a statistically significant difference from the indicated value $\left({ }^{* *} P<0.01,{ }^{* * *} P<0.001\right)$. (b) The secretion of IL-10 in the medium of MG6 cells and primary cultured microglia after treatment with aloe-emodin, $(+)$-catechin, and piceatannol. The results show the mean IL-10 secreted in the culture medium after treatment with aloe-emodin $(10 \mu \mathrm{M}$ for $48 \mathrm{~h})$ and $(+)$-catechin $(30 \mu \mathrm{M}$ for $48 \mathrm{~h})$ with the minimum effective doses for the most effective experimental time points. The most effective experimental time points were determined after examination of three different experimental time points $(24,48$ and $72 \mathrm{~h}$ ). On the other hand, piceatannol with $100 \mu \mathrm{M}$ was applied for $72 \mathrm{~h}$. The results represent the mean \pm SEM of three independent experiments. The asterisks indicate a statistically significant difference from the value in untreated cells $\left({ }^{* * *} P<0.001\right)$.

the present study suggests that the anti-inflammatory and antioxidant activities of (+)-catechin and aloe-emodin are due their abilities to induce the production and secretion of IL-10.

It has been also reported that the gene delivery of IL-10adeno-associated virus significantly reduces neuroinflammation, enhances neurogenesis, and improves the spatial cognitive dysfunction in a transgenic AD mouse model [33]. Furthermore, it has been suggested that the IL-10 gene polymorphisms process, which favours the development of $\mathrm{AD}$, reinforces the link between inflammation and cognitive decline in elderly people [34]. IL-10 has been shown to reduce IL- $1 \beta$ production by preventing the excessive generation of reactive oxygen species from complex II in damaged mitochondria and limiting the inflammasome activation in macrophages [30], which are characteristics of aged microglia associated with cognitive dysfunction $[35,36]$. These findings support the notion that IL-10 may ameliorate neuroinflammation, cognitive dysfunction, and neurodegeneration associated with AD. Therefore, $R t$ may be useful for 
the pharmacological intervention against excessive inflammatory and oxidative responses associated with $\mathrm{AD}$ by inducing the production of IL-10 by microglia, because some of active components of $R t$ including $(+)$-catechin can cross the blood-brain barrier [37].

\section{Conclusions}

$R t$ downregulates the production of proinflammatory and oxidative mediators, including IL- $1 \beta, \mathrm{TNF}-\alpha$, and NO, by cultured activated microglia through the production of IL-10. Two components of $R t$, aloe-emodin and (+)-catechin, are deemed responsible for the antineuroinflammatory and antioxidative effects of $R t$ through the secretion of IL-10 from microglia. Therefore, $R t$ may be useful for the pharmacological intervention against excessive inflammatory and oxidative responses associated with $\mathrm{AD}$ by inducing the production of IL-10 by microglia.

\section{Disclosure}

Hiroshi Nakanishi present address is Department of Pharmacology, Faculty of Pharmaceutical Sciences, Yasuda Women's University, Hiroshima 731-0153, Japan.

\section{Conflicts of Interest}

The authors declare no competing interests.

\section{Authors' Contributions}

Jie Meng performed the most of experiments, analyzed the data, and wrote the manuscript. Junjun Ni performed the experiments and analyzed the data. Zhou $\mathrm{Wu}$ analyzed the data and wrote the manuscript. Muzhou Jiang performed the experiments. Aiqin Zhu and Hong Qing provided materials and supervised some of the experiments. Hiroshi Nakanishi designed and supervised the experiments and wrote the manuscript.

\section{Acknowledgments}

This work was supported by Grants-in-Aid for Scientific Research (no. 17K17093 to Junjun Ni, nos. 16K11478 and $16 \mathrm{H} 0848$ to Zhou Wu, and no. $15 \mathrm{H} 05015$ to Hiroshi Nakanishi), MEXT, Japan.

\section{References}

[1] P. L. McGeer, E. McGeer, J. Rogers, and J. Sibley, "Anti-inflammatory drugs and Alzheimer disease," The Lancet, vol. 335, no. 8696, p. 1037, 1990.

[2] P. L. McGeer and E. G. McGeer, "The amyloid cascadeinflammatory hypothesis of Alzheimer disease: implications for therapy," Acta Neuropathologica, vol. 126, no. 4, pp. 479497, 2013.

[3] B. Zhang, C. Gaiteri, L.-G. Bodea et al., "Integrated systems approach identifies genetic nodes and networks in late-onset Alzheimer's disease," Cell, vol. 153, no. 3, pp. 707-720, 2013.
[4] A. Olmos-Alonso, S. T. T. Schetters, S. Sri et al., "Pharmacological targeting of CSF1R inhibits microglial proliferation and prevents the progression of Alzheimer's-like pathology," Brain, vol. 139, no. 3, pp. 891-907, 2016.

[5] E. E. Spangenberg, R. J. Lee, A. R. Najafi et al., "Eliminating microglia in Alzheimer's mice prevents neuronal loss without modulating amyloid- $\beta$ pathology," Brain, vol. 139, no. 4, pp. 1265-1281, 2016.

[6] D. K. Choi, S. Koppula, and K. Suk, "Inhibitors of microglial neurotoxicity: focus on natural products," Molecules, vol. 16, no. 2, pp. 1021-1043, 2011.

[7] Z. Wu, A. Zhu, F. Takayama et al., "Brazilian green propolis suppresses the hypoxia-induced neuroinflammatory responses by inhibiting NF- $\kappa$ B activation in microglia," Oxidative Medicine and Cellular Longevity, vol. 2013, Article ID 906726, 10 pages, 2013.

[8] J. Ni, Z. Wu, J. Meng et al., "The neuroprotective effects of Brazilian green propolis on neurodegenerative damage in human neuronal SH-SY5Y cells," Oxidative Medicine and Cellular Longevity, vol. 2017, Article ID 7984327, 13 pages, 2017.

[9] X. Peigen, H. Liyi, and W. Liwei, "Ethnopharmacologic study of Chinese rhubarb," Journal of Ethnopharmacology, vol. 10, no. 3, pp. 275-293, 1984.

[10] K. Frei, H. Lins, C. Schwerdel, and A. Fontana, "Antigen presentation in the central nervous system. The inhibitory effect of IL-10 on MHC class II expression and production of cytokines depends on the inducing signals and the type of cell analyzed," The Journal of Immunology, vol. 152, no. 6, pp. 2720-2728, 1994.

[11] T. Mizuno, M. Sawada, T. Marunouchi, and A. Suzumura, "Production of interleukin-10 by mouse glial cells in culture," Biochemical and Biophysical Research Communications, vol. 205, no. 3, pp. 1907-1915, 1994.

[12] P. A. Lodge and S. Sriram, "Regulation of microglial activation by TGF- $\beta$, IL-10, and CSF-1," Journal of Leukocyte Biology, vol. 60 , no. 4, pp. 502-508, 1996.

[13] L. Minghetti, E. Polazzi, A. Nicolini, and G. Levi, "Opposite regulation of prostaglandin $\mathrm{E}_{2}$ synthesis by transforming growth factor- $\beta 1$ and interleukin 10 in activated microglial cultures," Journal of Neuroimmunology, vol. 82, no. 1, pp. 31-39, 1998.

[14] G. M. O'Keefe, V. T. Nguyen, and E. N. Benveniste, “Class II transactivator and class II MHC gene expression in microglia: modulation by the cytokines TGF- $\beta$, IL- 4 , IL-13 and IL-10," European Journal of Immunology, vol. 29, no. 4, pp. 12751285, 1999.

[15] M. Sawada, A. Suzumura, H. Hosoya, T. Marunouchi, and T. Nagatsu, "Interleukin-10 inhibits both production of cytokines and expression of cytokine receptors in microglia," Journal of Neurochemistry, vol. 72, no. 4, pp. 1466-1471, 1999.

[16] P. Shrikant, E. Weber, T. Jilling, and E. N. Benveniste, "Intercellular adhesion molecule-1 gene expression by glial cells. Differential mechanisms of inhibition by IL-10 and IL6," The Journal of Immunology, vol. 155, no. 3, pp. 14891501, 1995.

[17] S. Hu, C. C. Chao, L. C. Ehrlich et al., "Inhibition of microglial cell RANTES production by IL-10 and TGF- $\beta$," Journal of Leukocyte Biology, vol. 65, no. 6, pp. 815-821, 1999.

[18] A. F. Richwine, N. L. Sparkman, R. N. Dilger, J. B. Buchanan, and R. W. Johnson, "Cognitive deficits in interleukin-10- 
deficient mice after peripheral injection of lipopolysaccharide," Brain, Behavior, and Immunity, vol. 23, no. 6, pp. 794802, 2009.

[19] K. W. Moore, R. de Waal Malefyt, R. L. Coffman, and A. O'Garra, "Interleukin-10 and the interleukin-10 receptor," Annual Review of Immunology, vol. 19, no. 1, pp. 683-765, 2001.

[20] A. Ledeboer, J. J. P. Brevé, A. Wierinckx et al., "Expression and regulation of interleukin-10 and interleukin-10 receptor in rat astroglial and microglial cells," European Journal of Neuroscience, vol. 16, no. 7, pp. 1175-1185, 2002.

[21] F. Zhang, J. Liu, and J.-S. Shi, “Anti-inflammatory activities of resveratrol in the brain: role of resveratrol in microglial activation," European Journal of Pharmacology, vol. 636, no. 1-3, pp. 1-7, 2010.

[22] J. Song, S. Cheon, W. Jung, W. Lee, and J. Lee, "Resveratrol induces the expression of interleukin-10 and brain-derived neurotrophic factor in BV2 microglia under hypoxia," International Journal of Molecular Sciences, vol. 15, no. 9, pp. 1551215529, 2014.

[23] A. Cianciulli, T. Dragone, R. Calvello et al., "IL-10 plays a pivotal role in anti-inflammatory effects of resveratrol in activated microglia cells," International Immunopharmacology, vol. 24, no. 2, pp. 369-376, 2015.

[24] C. B. Larmonier, J. K. Uno, K.-M. Lee et al., "Limited effects of dietary curcumin on Th-1 driven colitis in IL-10 deficient mice suggest an IL-10-dependent mechanism of protection," American Journal of Physiology-Gastrointestinal and Liver Physiology, vol. 295, no. 5, pp. G1079-G1091, 2008.

[25] T. Takenouchi, K. Ogihara, M. Sato, and H. Kitani, "Inhibitory effects of U73122 and U73343 on $\mathrm{Ca}^{2+}$ influx and pore formation induced by the activation of $\mathrm{P} 2 \mathrm{X} 7$ nucleotide receptors in mouse microglial cell line," Biochimica et Biophysica Acta (BBA) - General Subjects, vol. 1726, no. 2, pp. 177-186, 2005.

[26] D. F. Sastradipura, H. Nakanishi, T. Tsukuba et al., "Identification of cellular compartments involved in processing of cathepsin E in primary cultures of rat microglia," Journal of Neurochemistry, vol. 70, no. 5, pp. 2045-2056, 1998.

[27] O. Yasuhara, I. Akiguchi, S. Nakamura et al., "Pancreastatinlike immunoreactivity in globular dystrophic neurites of senile plaques in brains of patients with Alzheimer's disease," Neuroscience Letters, vol. 208, no. 3, pp. 167-170, 1996.

[28] C.-M. Rangon, S. Haïk, B. A. Faucheux et al., "Different chromogranin immunoreactivity between prion and a-beta amyloid plaque," NeuroReport, vol. 14, no. 5, pp. 755-758, 2003.

[29] Z. Wu, L. Sun, S. Hashioka et al., "Differential pathways for interleukin- $1 \beta$ production activated by chromogranin $\mathrm{A}$ and amyloid $\beta$ in microglia," Neurobiology of Aging, vol. 34, no. 12, pp. 2715-2725, 2013.

[30] W. K. E. Ip, N. Hoshi, D. S. Shouval, S. Snapper, and R. Medzhitov, "Anti-inflammatory effect of IL-10 mediated by metabolic reprogramming of macrophages," Science, vol. 356, no. 6337, pp. 513-519, 2017.

[31] S. S. Syed Hussein, M. N. A. Kamarudin, and H. Abdul Kadir, "(+)-Catechin attenuates NF- $\kappa$ B activation through regulation of Akt, MAPK, and AMPK signaling pathways in LPS-induced BV-2 microglial cells," The American Journal of Chinese Medicine, vol. 43, no. 5, pp. 927-952, 2015.

[32] M.-Y. Park, H.-J. Kwon, and M.-K. Sung, "Evaluation of aloin and aloe-emodin as anti-inflammatory agents in aloe by using murine macrophages," Bioscience, Biotechnology, and Biochemistry, vol. 73, no. 4, pp. 828-832, 2009.

[33] T. Kiyota, K. L. Ingraham, R. J. Swan, M. T. Jacobsen, S. J. Andrews, and T. Ikezu, "AAV serotype 2/1-mediated gene delivery of anti-inflammatory interleukin-10 enhances neurogenesis and cognitive function in APP+PS1 mice," Gene Therapy, vol. 19, no. 7, pp. 724-733, 2012.

[34] C. A. Magalhães, M. d. G. Carvalho, L. P. d. Sousa, P. Caramelli, and K. B. Gomes, "Alzheimer's disease and cytokine IL-10 gene polymorphisms: is there an association?," Arquivos de Neuro-Psiquiatria, vol. 75, no. 9, pp. 649-656, 2017.

[35] H. Nakanishi and Z. Wu, "Microglia-aging: roles of microglial lysosome- and mitochondria-derived reactive oxygen species in brain aging," Behavioural Brain Research, vol. 201, no. 1, pp. 1-7, 2009.

[36] H. Nakanishi, Y. Hayashi, and Z. Wu, "The role of microglial mtDNA damage in age-dependent prolonged LPS-induced sickness behavior," Neuron Glia Biology, vol. 7, no. 1, pp. 1723, 2011.

[37] L. Wu, Q. L. Zhang, X. Y. Zhang et al., "Pharmacokinetics and blood-brain barrier penetration of (+)-catechin and (-)-epicatechin in rats by microdialysis sampling coupled to highperformance liquid chromatography with chemiluminescence detection," Journal of Agricultural and Food Chemistry, vol. 60, no. 37, pp. 9377-9383, 2012. 


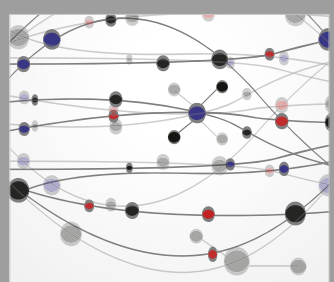

The Scientific World Journal
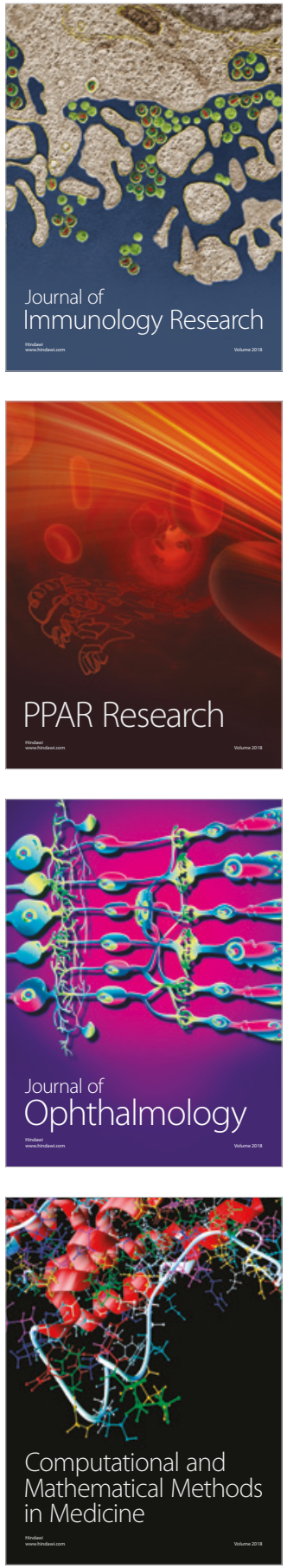

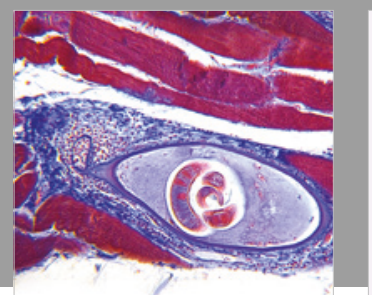

Gastroenterology Research and Practice

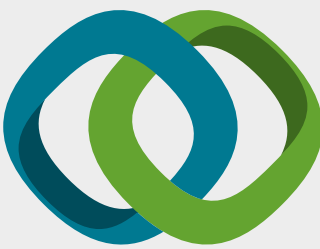

\section{Hindawi}

Submit your manuscripts at

www.hindawi.com
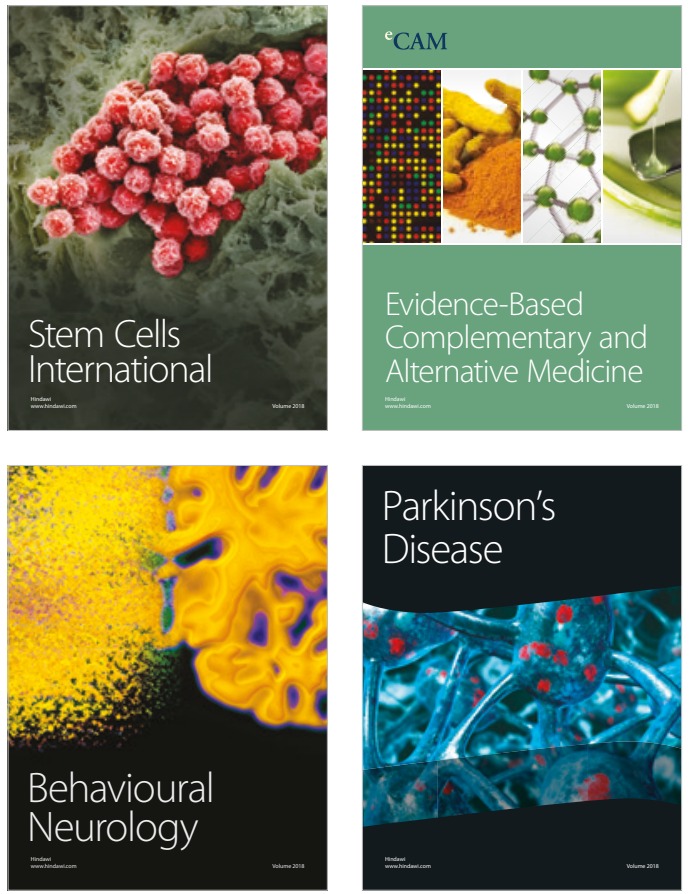

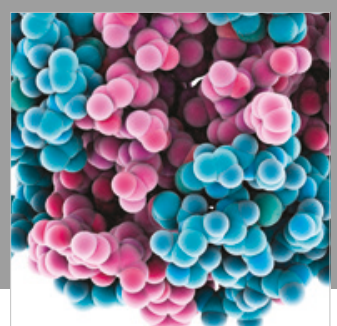

ournal of

Diabetes Research

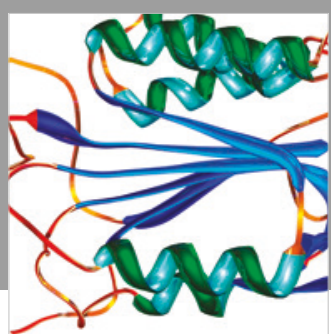

Disease Markers
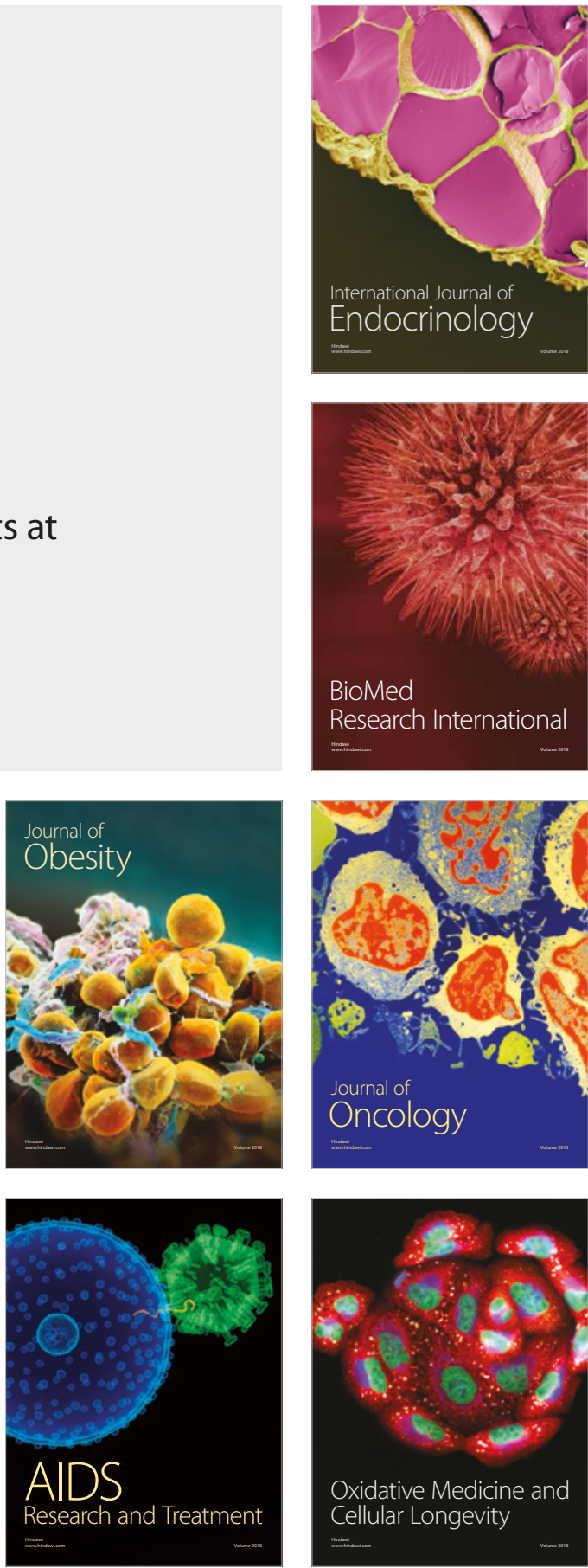